\title{
Atmospheric mercury over sea ice during the OASIS-2009 campaign
}

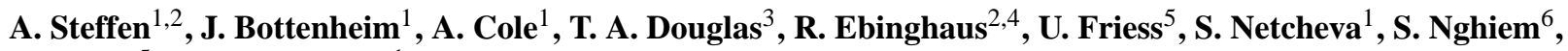 \\ H. Sihler ${ }^{5}$, and R. Staebler ${ }^{1}$ \\ ${ }^{1}$ Air Quality Processes Research Section, Environment Canada, 4905 Dufferin St., Toronto, Ontario M3H 5T4, Canada, \\ ${ }^{2}$ Leuphana University Lüneburg, Institute of Sustainable \& Environmental Chemistry (ISEC), Scharnhorststr. 1/13, \\ 21335 Lüneburg, Germany \\ ${ }^{3}$ US Army Cold Regions Research \& Engineering Laboratory, Fort Wainwright, Alaska 99703, USA \\ ${ }^{4}$ Helmholtz-Zentrum Geesthacht, Institute of Coastal Research, Department for Environmental Chemistry, Max-Planck-Str. 1, \\ 21502 Geesthacht, Germany \\ ${ }^{5}$ Institute of Environmental Physics, University of Heidelberg, Im Neuenheimer Feld 229, 69120 Heidelberg, Germany \\ ${ }^{6}$ Jet Propulsion Laboratory, California Institute of Technology, Pasadena, California, USA
}

Correspondence to: A. Steffen (alexandra.steffen@ec.gc.ca)

Received: 3 February 2013 - Published in Atmos. Chem. Phys. Discuss.: 4 March 2013

Revised: 10 June 2013 - Accepted: 23 June 2013 - Published: 24 July 2013

\begin{abstract}
Measurements of gaseous elemental mercury (GEM), reactive gaseous mercury (RGM) and particulate mercury $(\mathrm{PHg})$ were collected on the Beaufort Sea ice near Barrow, Alaska, in March 2009 as part of the Ocean-Atmosphere-Sea Ice-Snowpack (OASIS) and OASISCanada International Polar Year programmes. These results represent the first atmospheric mercury speciation measurements collected on the sea ice. Concentrations of PHg averaged $393.5 \mathrm{pg} \mathrm{m}^{-3}$ (range $47.1-900.1 \mathrm{pg} \mathrm{m}^{-3}$ ) and RGM concentrations averaged $30.1 \mathrm{pg} \mathrm{m}^{-3}$ (range $3.5-105.4 \mathrm{pg} \mathrm{m}^{-3}$ ) during the two-week-long study. The mean concentration of GEM during the study was $0.59 \mathrm{ng} \mathrm{m}^{-3}$ (range $0.01-1.51 \mathrm{ng} \mathrm{m}^{-3}$ ) and was depleted compared to annual Arctic ambient boundary layer concentrations. It is shown that when ozone $\left(\mathrm{O}_{3}\right)$ and bromine oxide $(\mathrm{BrO})$ chemistry were active there is a positive linear relationship between GEM and $\mathrm{O}_{3}$, a negative one between $\mathrm{PHg}$ and $\mathrm{O}_{3}$, a positive correlation between $\mathrm{RGM}$ and $\mathrm{BrO}$, and none between RGM and $\mathrm{O}_{3}$. For the first time, GEM was measured simultaneously over the tundra and the sea ice. The results show a significant difference in the magnitude of the emission of GEM from the two locations, with significantly higher emission over the tundra. Elevated chloride levels in snow over sea ice are proposed to be the cause of lower GEM emissions over the sea ice because chloride has been shown to suppress photoreduction processes of RGM to GEM in snow. Since the snowpack on sea ice retains more mercury
\end{abstract}

than inland snow, current models of the Arctic mercury cycle may greatly underestimate atmospheric deposition fluxes because they are based predominantly on land-based measurements. Land-based measurements of atmospheric mercury deposition may also underestimate the impacts of sea ice changes on the mercury cycle in the Arctic. The predicted changes in sea ice conditions and a more saline future snowpack in the Arctic could enhance retention of atmospherically deposited mercury and increase the amount of mercury entering the Arctic Ocean and coastal ecosystems.

\section{Introduction}

Mercury $(\mathrm{Hg})$ is a toxic pollutant found in all compartments of the environment. Its presence in the environment derives from both natural and anthropogenic sources. At elevated levels, in a methylated form, mercury can be a neurotoxin to wildlife and humans. Thus, understanding how it enters and is distributed within ecosystems is crucial for the protection of those living in them. The Arctic is vulnerable to mercury pollution and much has been published on its cycling in this unique environment (Steffen et al., 2008; Douglas et al., 2012b; Stern et al., 2012). The average northern hemispheric gaseous elemental mercury (GEM) concentration has been reported to be approximately $1.7 \mathrm{ng} \mathrm{m}^{-3}$ in 2003 (Slemr et al., 2003), with more recent reports showing 
lower concentrations at some sites (Ebinghaus et al., 2011; Slemr et al., 2011). The mean GEM concentration for the high Arctic site Alert has been reported to be 1.54 annually and $1.39 \mathrm{ng} \mathrm{m}^{-3}$ in the spring season (Steffen et al., 2005), though also declining in recent years (Cole and Steffen, 2010).

The Arctic atmosphere plays a key role in controlling mercury deposition to snow and ice surfaces. In the spring, through a series of photochemically initiated reactions, mercury is oxidized from its predominant form GEM $(\mathrm{Hg}(0))$ in the air to inorganic $\mathrm{Hg}(\mathrm{II})$ species, either as a gas or associated to particles. These gaseous or particle-bound $\mathrm{Hg}$ (II) species are termed reactive gaseous mercury (RGM) or particulate mercury $(\mathrm{PHg})$, respectively. While this oxidation process is not Arctic specific, the efficiency in the Arctic spring is remarkable whereby GEM is often depleted to levels below the detection limit. This process is termed an "atmospheric mercury depletion event" (AMDE) and is concurrent with the depletion of marine boundary layer ozone $\left(\mathrm{O}_{3}\right)$ (Steffen et al., 2008). Ozone is destroyed by bromine atoms that are produced through a series of photochemically initiated reactions from sea salts, and GEM is oxidized by bromine atoms either as $\mathrm{Br}$ or $\mathrm{BrO}$ (Simpson et al., 2007; Steffen et al., 2008). Both GEM and $\mathrm{O}_{3}$ depletions require the presence of sea salts, sunlight, stable boundary conditions and cold temperatures. At this time, RGM and PHg are operationally defined as mercury that adsorbs to a $\mathrm{KCl}$ denuder (gas phase) and mercury that is associated to particles $<2.5 \mu \mathrm{m}$ and collected on quartz filters, respectively. Concentrations of RGM and PHg vary by location and season; however, there are significant differences reported between temperate background sites and high Arctic sites (Cole et al., 2013). Background concentrations for several North American studies have been reported to range from approximately 2 to 25 and 1 to $54 \mathrm{pg} \mathrm{m}^{-3}$ for RGM and PHg, respectively (Poissant et al., 2005; Lynam and Keeler, 2006; Lyman and Gustin, 2008). In contrast, in the high Arctic at Alert, concentrations of RGM and $\mathrm{PHg}$ can range from approximately 0 to 340 and 0 to $700 \mathrm{pg} \mathrm{m}^{-3}$ for RGM and PHg, respectively, in the spring (Cobbett et al., 2007), but are generally lower the remainder of the year. Coastal observations have reported periodic near-complete conversion of GEM to RGM and/or PHg during the Arctic springtime; nevertheless, few to no data have been published from similar measurements collected on Arctic Ocean sea ice. The fate of mercury in the coastal environment has been the object of investigation for over a decade. It is believed that the majority of the $\mathrm{O}_{3}$ depletion events occur over the Arctic Ocean and those reported at coastal measurement sites are a result of depleted air masses that have travelled from the ocean to the site and not from local chemistry (Bottenheim and Chan, 2006). Strengthening the argument that this chemistry is initiated over the sea ice, near-complete $\mathrm{O}_{3}$ depletion was observed over Arctic Ocean sea ice on a German icebreaker in 2003 and on a sailboat expedition in 2008 (Jacobi et al., 2006; Bottenheim et al., 2009). Ozone lidar measurements onboard the Amundsen icebreaker also observed that depleted layers were always connected to the surface and that the probability of low ozone concentrations increased with the amount of time the advected air masses had spent close to the surface in the preceding six days (Seabrook et al., 2011). Until recently, logistical and technical challenges limited our ability to collect reliable atmospheric mercury speciation (GEM, RGM and $\mathrm{PHg}$ ) data immediately over the Arctic Ocean.

Over the springtime period, when GEM is converted in the air to $\mathrm{RGM} / \mathrm{PHg}$, there is often increased concentration of $\mathrm{Hg}$ in the underlying snowpack (Schroeder et al., 1998; Ebinghaus et al., 2002; Lindberg et al., 2002; Berg et al., 2003b; Skov et al., 2004; Steffen et al., 2008). It has been suggested that there are mechanisms within the top layer of the snowpack that release some of that deposited mercury back to the air as GEM, which then makes it again available for oxidation and deposition (Lalonde et al., 2002; Dommergue et al., 2003; Ferrari et al., 2004, 2005; Kirk et al., 2006; Cobbett et al., 2007; Constant et al., 2007; Dommergue et al., 2007; Durnford and Dastoor, 2011; Douglas et al., 2012b). Thus, it has been reported that the level of mercury drops off with time in the snowpack (following atmospheric deposition) as a result of photoreduction processes (Poulain et al., 2004; Kirk et al., 2006; Constant et al., 2007; Sherman et al., 2010; Durnford and Dastoor, 2011). A question that remains is how much of this deposited $\mathrm{Hg}$ is retained by snowpacks or entrained in melt water and how much is emitted to the air? Currently, modellers have made assumptions on the amount of GEM re-emitted from the snow surface in their simulation models. Fisher et al. (2012) use $60 \%$ re-emission in their standard simulation, while others use $59 \%$ and $60 \%$ as the estimates (Dastoor et al., 2008; Holmes et al., 2010). In an in-depth study, Durnford et al. (2012) determined modelled re-emission rates of $67 \%$ between $60^{\circ} \mathrm{N}$ and $66.5^{\circ} \mathrm{N}$ and $75 \%$ from $66.5^{\circ} \mathrm{N}$ to $90^{\circ} \mathrm{N}$ as a result of the mechanisms discussed above. In a general review, Douglas et al. (2012b) estimated an overall re-emission of between 60 and $80 \%$ of deposited Hg.

As part of the March 2009 International Polar Year (IPY) Ocean-Atmosphere-Sea Ice-Snowpack (OASIS) international and OASIS-Canada campaigns in Barrow, Alaska, atmospheric mercury speciation measurements and a suite of meteorological, $\mathrm{O}_{3}$ and bromine oxide $(\mathrm{BrO})$ measurements including snowpack chemical composition measurements were made over the Arctic sea ice. Other studies have collected information from platforms in the high Arctic such as icebreakers (Aspmo et al., 2006; Chaulk et al., 2011), but none have measured atmospheric mercury species directly on the unperturbed ice near open leads or freshly formed sea ice. GEM measurements were made simultaneously over the tundra snowpack at an inland location for comparison. Results from this novel experiment provide new insights into the behaviour of atmospheric mercury in the Arctic Ocean environment. 


\section{Methods}

\subsection{Logistics and sites}

The study took place near Barrow, Alaska, from 5 March to 4 April 2009. Most of the experiment described in this study was undertaken over the Chukchi Sea near the town of Barrow. The instrument boxes, called the "Out On The Ice" (OOTI) system, were towed on specially designed sleds behind snowmobiles onto the Arctic sea ice as close as possible to open leads. Figure 1a shows a map of the site locations and a satellite image of the sea ice conditions on 19 March. The first site $\left(71.29^{\circ} \mathrm{N}, 156.85^{\circ} \mathrm{W}\right)$ was initially close to an open lead but the lead closed within the first day of sampling. The instruments were moved to other locations on two separate occasions on $19 \operatorname{March}\left(71.36^{\circ} \mathrm{N}, 156.69^{\circ} \mathrm{W}\right)$ and $23 \mathrm{March}$ $\left(71.36^{\circ} \mathrm{N}, 156.66^{\circ} \mathrm{W}\right)$. The ice surface for the 3 sites can be described as follows: Site 1 - windblown snow over fewday-old frost flowers; Site 2 - snow over sea ice; and Site 3 - 1- to 2-day-old frost flowers (FFs). Sites 1, 2 and 3 were located 1.4, 2.9 and $2.2 \mathrm{~km}$ from the shoreline, respectively. The distance between sites 1 and 2, and sites 2 and 3 was approximately 10 and $1 \mathrm{~km}$, respectively. Figure $1 \mathrm{~b}$ shows the experimental set-up on the sea ice. The instrumentation was housed in two separate aluminum boxes (Box 1 and Box 2) that were lined with insulating foam and maintained at a temperature above freezing either through instrument-generated heat or with a heated blanket. Box 1 housed the meteorological instrumentation, the ozone instruments and the miniMAX-DOAS spectrometer. Attached to the top of the box was a telescope for the MAX-DOAS for scanning over the ice. Box 2 housed the mercury speciation instrumentation. All the instruments were powered using a $5 \mathrm{~kW}$ gas generator that was located approximately $17 \mathrm{~m}$ downwind of the sample inlets. Data was collected on a semi-continuous basis as per the instrument methodology, and data gaps occurred during site transfers or when the generator stopped working due to mechanical problems associated with the extremely cold conditions. Once the equipment was moved to a site, the systems were set up as shown in the photo in Fig. 1b. The inlet of the $\mathrm{Hg}$ speciation system was approximately $15 \mathrm{~cm}$ above the snowpack or ice surface, the ozone inlet was between at 1 and $10 \mathrm{~cm}$ above the surface, and the meteorological data were collected between 215 and $300 \mathrm{~cm}$ from the surface. A second mercury system was located inland with an inlet height of $85 \mathrm{~cm}$ from the snow surface. This "tundra" site was $1.2 \mathrm{~km}$ inland and $7.6 \mathrm{~km}$ from site $1,4.6 \mathrm{~km}$ from site 2 and $4.5 \mathrm{~km}$ from site 3 .

\subsection{Atmospheric mercury}

Atmospheric mercury was collected using a Tekran ${ }^{\circledR}$ (Toronto, Ontario, Canada) 2537A/1130/1135 mercury speciation system that measures the concentration of GEM, RGM and PHg. GEM is collected on gold traps, RGM is col-

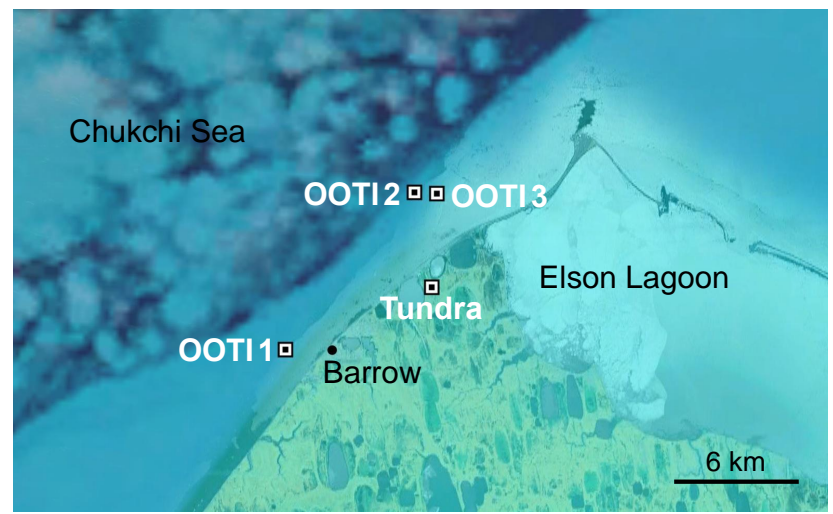

Fig. 1a. Field experimental sites around Barrow near the northernmost tip of Alaska. OOTI 1 at $71.29^{\circ} \mathrm{N}, 156.85^{\circ} \mathrm{W}$; OOTI 2 at $71.36^{\circ} \mathrm{N}, 156.69^{\circ} \mathrm{W}$; OOTI 3 at $71.36^{\circ} \mathrm{N}, 156.66^{\circ} \mathrm{W}$; and Tundra at $71.32^{\circ} \mathrm{N}, 156.66^{\circ} \mathrm{W}$. The MODIS Aqua satellite is translucently overlain to show sea ice conditions in the Chukchi Sea on 19 March 2009.

lected on $\mathrm{KCl}$ coated denuders and PHg is collected on quartz filters ( $2.5 \mu \mathrm{m}$ cutoff from the impactor set-up). The method has been described in detail elsewhere (Landis et al., 2002; Steffen et al., 2008). GEM samples were collected continuously with 5 min intervals (using 2 traps), while RGM/PHg were collected hourly and then analysed over the subsequent hour. All the data were quality controlled manually but following protocols used by Environment Canada (Steffen et al., 2012b). Hourly averaged data were produced based on the start and end times of the $\mathrm{Hg}$ speciation collection (as it does not always start at the top of the hour). Thus, all ancillary data were averaged at the same start and end times as the $\mathrm{Hg}$ speciation for appropriate comparison of data. Measurements of GEM, RGM and PHg were made at the OOTI site. GEM was collected at the tundra site with another speciation system. RGM and PHg from the tundra site are not reported here due to instrument problems.

\subsection{Meteorological information}

Wind speed and direction were measured using a propeller anemometer (Model 05103, R. M. Young, Traverse City, MI, USA) at $3.0 \mathrm{~m}$ above the surface and a sonic anemometer (CSAT-3, Campbell Scientific, Logan, UT, USA) at $2.2 \mathrm{~m}$. The orientation relative to absolute north was determined by hand-held GPS (Garmin Etrex). To determine temperatures, copper-constantan thermocouples were located inside passive radiation shields at $1.38,0.1 \mathrm{~m}$ above and $0.05 \mathrm{~m}$ under the snow surface. A platinum resistance thermometer/relative humidity sensor (HMP45C, Campbell Scientific, Logan, UT, USA) inside a passive radiation shield was located at $2.3 \mathrm{~m}$. Shortwave radiation (incoming and reflected) was monitored using silicon photovoltaic detectors (Li-190S, Li-200S, LiCor, Lincoln, NB, USA). Pressure was measured on site with a barometer (Model 61202V, RM Young). 


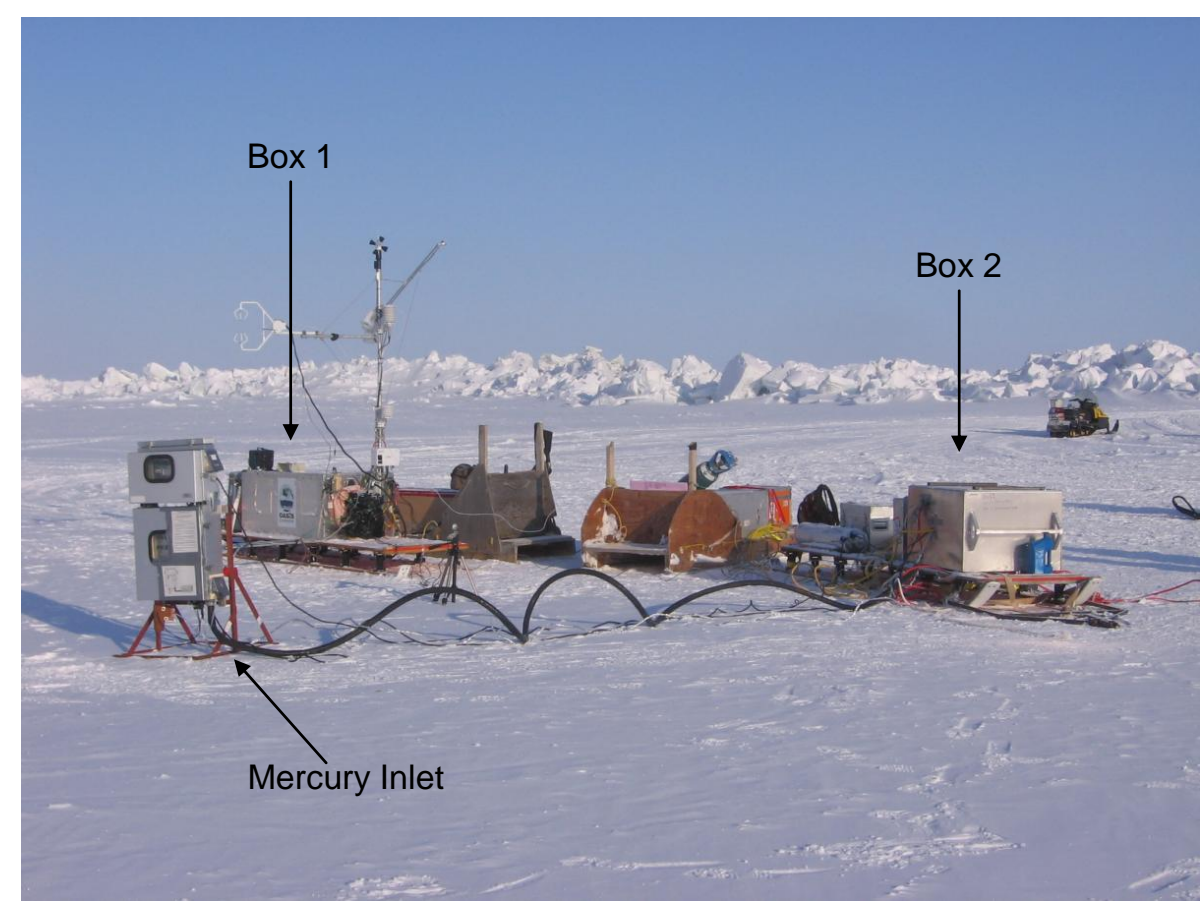

Fig. 1b. Experimental set-up of the Out On The Ice (OOTI) system. Box 1 housed the meteorological, MAX-DOAS and ozone instrumentation. Box 2 housed the mercury instrumentation. The inlet for the atmospheric mercury measurement is shown.

\subsection{Ozone}

At the OOTI site, a Model 205 dual-cell ozone monitor, manufactured by 2B Technology (Boulder, Colorado, USA), was used to measure surface-level ozone. Ambient air was sampled through $\frac{1}{4}$ " PFA tubing. A Teflon $2 \mu \mathrm{m}$-pore-sized filter was used to prevent penetration of any particles into the measuring cells. The instrument was calibrated at the beginning and end of the field campaign. Its zero was monitored for possible drift through regular zero measurements using an external ozone scrubber on the days when ozone was above a threshold of $10 \mathrm{ppb}$.

\subsection{Bromine monoxide}

Differential optical absorption spectroscopy (DOAS) can be used to quantify the column abundances of trace gases, such as bromine oxide $(\mathrm{BrO})$, along a well-defined light path. These trace gases are determined using specific narrow-band absorption structures in the ultraviolet and visible spectral regions. The $\mathrm{BrO}$ measurements described in this paper were collected with a long-path DOAS (LP-DOAS) instrument (Platt and Stutz, 2008). The general set-up used in this study is described elsewhere (Frieß et al., 2011; Liao et al., 2011). The LP-DOAS telescope was located approximately $1 \mathrm{~km}$ inland on a building facing northwest. Two retro reflectors were installed $3623 \mathrm{~m}$ and $1074 \mathrm{~m}$ away from the telescope and provided a light path of $7246 \mathrm{~m}$ and $2148 \mathrm{~m}$, respectively. The long light path was used under favourable meteorolog- ical conditions, whereas the short light path was used during periods of low visibility owing to fog, blowing snow or occasionally occurring mirages. Depending on meteorological conditions, spectra were recorded with integration times ranging between 1 and $50 \mathrm{~s}$. The LP-DOAS light paths were almost parallel to the coast and are therefore are used to represent the same air mass. Liao et al. (2011) concluded that $\mathrm{BrO}$ is often distributed homogeneously on spatial scales of up to at least $4 \mathrm{~km}$. Since the measurements from the LPDOAS were collected within this distance, they are considered representative at the OOTI site.

\subsection{Snow and ion chromatography samples}

Samples for major ion analyses were collected into precleaned high-density polyethylene (HDPE) bags using precleaned HDPE scoops. Samples were stored frozen until arrival at the laboratory where they were allowed to melt to room temperature and were filtered through tracemetal-grade nitric-acid-washed $0.45 \mathrm{~mm}$ polypropylene filters. Frost flower samples were diluted with $18 \mathrm{M} \Omega$ water 1000 times (by volume) prior to analysis. All sample dilutions were done in quadruplicate to assess cross-sample variation in the dilution process and were determined to be repeatable within $5 \%$ of the concentration values. Cation and anion concentrations were quantified on a Dionex ICS-3000 ion chromatograph with an AS-19 anion column and CS-12 cation column (Dionex Corporation, Sunnyvale, California) at the Cold Regions Research and Engineering Laboratory 
Alaska Geochemistry Laboratory. Each sample had a $10 \mathrm{~mL}$ injection volume. A gradient method using potassium hydroxide eluent ranged from $20 \mathrm{mM}$ to $35 \mathrm{mM}$ for anion analyses. Cation analyses used methane sulfonic acid eluent with a concentration of $25 \mathrm{mM}$ in isocratic mode. The system

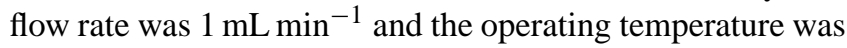
$30^{\circ} \mathrm{C}$. The ion chromatograph was calibrated through repeat analysis of five calibration standards with concentrations ranging from 0.5 to $120 \mathrm{mg} \mathrm{L}^{-1}$ (within the range of analyses). Laboratory analytical anion and cation standards with values from 1 to $100 \mathrm{mg} \mathrm{L}^{-1}$ were analysed repeatedly to verify system calibration and assess analytical precision. Based on these analyses the calculated precision for the analyses is $5 \%$. Peaks were identified using Chromeleon (Dionex, Sunnyvale, California) and were verified visually.

\subsection{MAX-DOAS}

A mini-Multi Axis Differential Optical Absorption Spectroscopy (MAX-DOAS) system was used to record the aerosol extinction vertical profiles. This instrument is based on the Ocean Optics Inc. USB2000 miniature spectrometer (Hoffmann Messtechnik GmbH) (Hönninger and Platt, 2002; Frieß et al., 2004, 2006, 2011; Wagner et al., 2004) with a spectral resolution of $0.7 \mathrm{~nm}$. Scattered sun light was collected by rotating telescope from a series of elevation angles: $2^{\circ}, 5^{\circ}, 10^{\circ}$ and $20^{\circ}$ and $90^{\circ}$ (zenith orientation). Differential slant column densities (DSCDs) are directly measured from the instrument and represent the integrated concentrations of the absorbers along the scattered light path relative to the absorbers in measured reference spectrum selected from zenith observations. The vertical column density (VCD) is the vertically integrated trace gas concentration and is independent from the line of sight and the observed light path. DSCD and VCD are linked through an air mass factor $\mathrm{AMF}=\mathrm{DSCD} / \mathrm{VCD}$ which reflects the radiative transfer within the atmosphere and is determined through radiative transfer models (RTMs). Various aerosol scenarios were simulated using the radiative transfer model McArtim (Deutchmann, 2009) at $361 \mathrm{~nm}$. Aerosol extinction values between 0.02 and $1 \mathrm{~km}^{-1}$ were used in the simulations with different profiles (with variable thickness) closely confined in a narrow layer over the surface and extending up to $2500 \mathrm{~m}$ in the atmosphere from the surface.

\section{Results and discussion}

\subsection{Mercury measurements over the sea ice}

The atmospheric mercury species measured during this campaign include gaseous elemental mercury (GEM), reactive gas phase mercury (RGM) and particulate mercury $(\mathrm{PHg})$. Figure 2 shows the time series of GEM, RGM and PHg measured on the sea ice from 14 to 26 March 2009. Table 1 shows the descriptive statistics of this data set with a com-
Table 1. Mercury concentration data descriptive statistics from measurements over the sea ice and tundra.

\begin{tabular}{lcccc}
\hline & $\begin{array}{c}\text { GEM Ice } \\
\left(\mathrm{ng} \mathrm{m}^{-3}\right)\end{array}$ & $\begin{array}{c}\text { PHg Ice } \\
\left(\mathrm{pg} \mathrm{m}^{-3}\right)\end{array}$ & $\begin{array}{c}\text { RGM Ice } \\
\left(\mathrm{pg} \mathrm{m}^{-3}\right)\end{array}$ & $\begin{array}{c}\text { GEM Tundra } \\
\left(\mathrm{ng} \mathrm{m}^{-3}\right)\end{array}$ \\
\hline Mean & 0.59 & 393.49 & 30.10 & 0.79 \\
Median & 0.53 & 332.76 & 25.04 & 0.75 \\
Std. Dev & 0.40 & 236.74 & 23.69 & 0.56 \\
Max & 1.51 & 900.11 & 105.40 & 2.92 \\
Min & 0.01 & 47.09 & 3.52 & 0.00 \\
$R^{2}{\text { vs } \mathrm{O}_{3}}$ & 0.76 & 0.61 & 0.10 & 0.52 \\
\hline
\end{tabular}

parison to the tundra site. A GEM concentration of less than $0.77 \mathrm{ng} \mathrm{m}^{-3}$ was calculated as the upper limit indicating that an AMDE is occurring. This value is two standard deviations below the September-December mean GEM concentration for Barrow (from 2007 to 2009) (Steffen et al., 2012a). In this study, the GEM concentrations are below this threshold for $63 \%$ of the total number of hourly averages, with a mean concentration of $0.59 \pm 0.40 \mathrm{ng} \mathrm{m}^{-3}$. The considerable variation that is associated with AMDEs is shown by the standard deviation for all the $\mathrm{Hg}$ parameters reported. Annual average GEM concentrations for Barrow (2007-2009) are $1.15 \mathrm{ng} \mathrm{m}^{-3}$ and are lower than the northern hemispheric average $\left(\sim 1.70 \mathrm{ng} \mathrm{m}^{-3}\right)$ (Slemr et al., 2003; Steffen et al., 2005). The PHg concentrations measured during this study are high, in comparison to temperate regions (Steffen et al., $2012 \mathrm{~b}$ ), with a mean concentration of $393 \pm 237 \mathrm{pg} \mathrm{m}^{-3}$ and a maximum of $900 \mathrm{pg} \mathrm{m}^{-3}$. RGM concentrations are lower than PHg, with a mean concentration of $30 \pm 24 \mathrm{pg} \mathrm{m}^{-3}$ and a maximum value of $105 \mathrm{pg} \mathrm{m}^{-3}$. These RGM concentrations are lower than others reported from Barrow (Lindberg et al., 2002) and we attribute the differences to spatial, seasonal and inter-annual variability. Figure 2 also shows the negative relationship between GEM concentration and $\mathrm{PHg} / \mathrm{RGM}$ concentration during the measured time period which is commonly associated with AMDE chemistry.

On 14 March, the instruments were installed on the sea ice and subsequently moved on 19 March (22:00 UTC) and 23 March (21:00 UTC) to OOTI sites 1-3, respectively, to assess different surfaces and proximity to open leads (Fig. 1a). The surfaces of the three sites ranged from a few-day-old frost flower field with some surface snow (new ice pan), an ice pan with surface snow and an ice pan with 1-2-day-old frost flowers in which we cut an open hole through the ice which quickly froze over. Frost flowers are formed from water vapour above the sea ice into intricate ice crystal clusters (Simpson et al., 2007; Douglas et al., 2012a) that have the appearance of flowers on the surface. Brine enriched in sea salts are wicked up through the ice into these crystals. These three surfaces all represent highly saline surface young (nilas) sea ice with some frost flowers. Figure 3 shows the Moderate Resolution Imaging Spectroradiometer (MODIS) satellite images of our sample locations. Bands 1, 2, and 7 


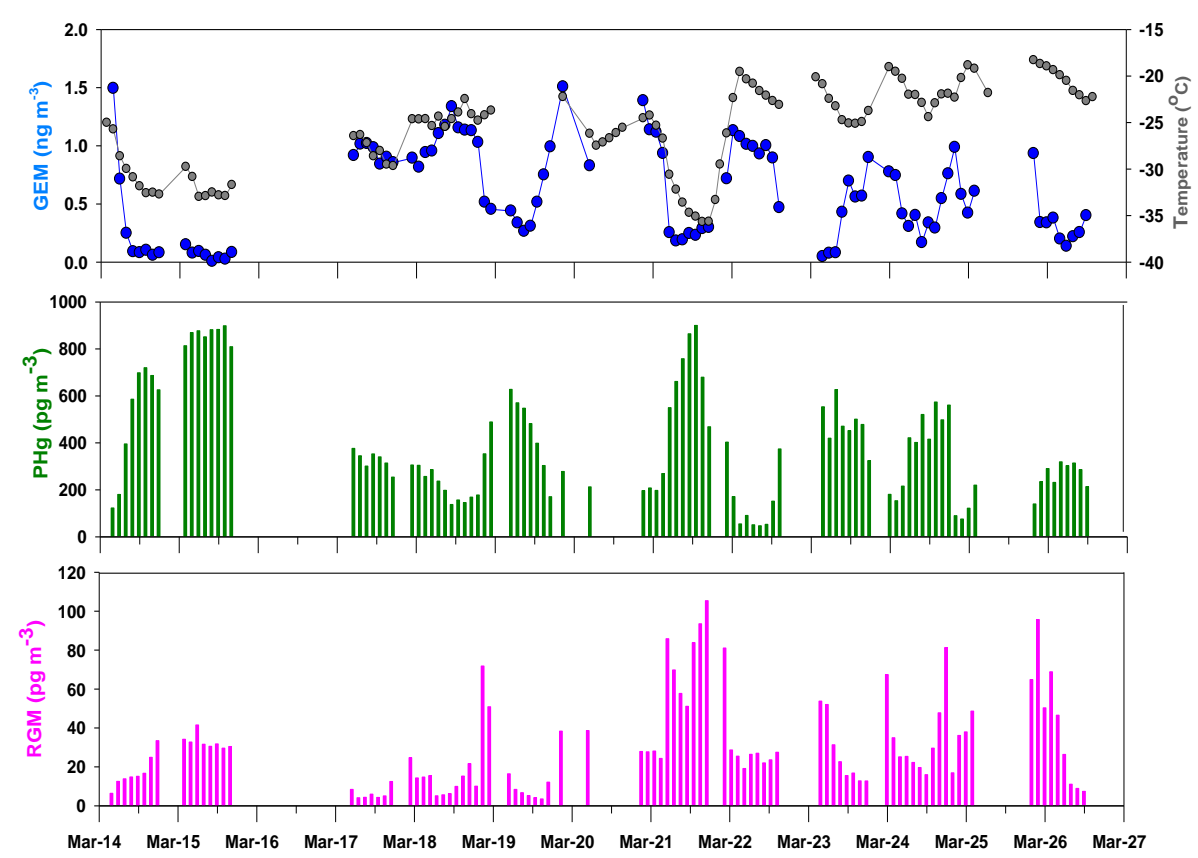

Fig. 2. Hourly speciation and air temperature data from over the ice. Gaseous elemental mercury (GEM, top) is reported in ng $\mathrm{m}^{-3}$, and reactive gaseous mercury (RGM, bottom) and particulate mercury $\left(\mathrm{PHg}\right.$, middle) are reported in $\mathrm{pg} \mathrm{m}^{-3}$. Air temperature is reported in ${ }^{\circ} \mathrm{C}$. The gaps in data indicate when the system was moved to a new site or when the power failed.

from the MODIS Aqua satellite are used to identify sea ice on 14-25 March when the sky was mostly clear. The satellite images, however, show that all locations are represented predominantly by first-year sea ice (blue) and some younger sea ice (darker blue) in refrozen areas where the ice cover was fractured by ice divergence. Since the surfaces of the sites are not vastly different in salinity and had little snow cover, for this paper we assume the surfaces are similar. From the satellite images, the interesting feature is the behaviour of the sea ice around the lead and this will be discussed later.

It is thought that the chemistry that leads to AMDEs occurs in the gas phase by oxidation of GEM to RGM. Once produced, RGM can partition/adsorb to particles in the air as PHg (Rutter and Schauer, 2007; Amos et al., 2012) or deposit to the surface. It has been theorized that the ratio of RGM to PHg reflects the transport distance of an air mass from where a depletion occurred and a low RGM : PHg indicates that the depletion occurred further away (Lindberg et al., 2002). Thus, if depletion events are initiated and occur over the Arctic Ocean, it might be reasonable to expect higher RGM than PHg concentrations when collecting measurements on the sea ice. However, the concentrations of PHg measured in this study are almost ten times higher than RGM over the sea ice. This was also observed in March 2008 from an icebreaker on the Beaufort Sea where the average concentration ratio of PHg: RGM was approximately 10.6 : 1 (Latonas, 2010). This result either dispels the theory that the ratio can indicate lifetime or shows that this study was not undertaken where depletion events occurred. Over the sea ice, the particle load in the air is likely the contributing factor in these elevated PHg concentrations. RGM can partition onto sea salt particles and other available surfaces (Rutter and Schauer, 2007). Both RGM and PHg have a higher dry deposition velocity $\left(0.5\right.$ to $6 \mathrm{~cm} \mathrm{~s}^{-1}$ and 0.02 to $2 \mathrm{~cm} \mathrm{~s}^{-1}$, respectively) than GEM ( 0.1 to $0.4 \mathrm{~cm} \mathrm{~s}^{-1}$ ) (Zhang et al., 2009) that allows for faster deposition. Amos et al. (2012) showed, in their model simulation, stronger deposition of oxidized $\mathrm{Hg}$ at higher latitudes. They also concluded that high PHg fractions are yielded in colder air masses with high aerosol burdens. This current study supports these modelled results qualitatively, with higher $\mathrm{PHg}$ : RGM ratios at lower temperatures (not shown), but, due to a lack of $\mathrm{PM}_{2.5}$ concentration data in this study, the partitioning could not be compared quantitatively.

\subsection{Particle load and mercury on the sea ice}

Using mini-MAX-DOAS, the position and thickness of the aerosol layer close to the study site can be modelled to confirm the presence or absence of aerosols as well as the position and thickness of the layer in the atmosphere. The sizes of the aerosols measured with the MAX-DOAS are not limited to the size of particles measured by the mercury instrument $(<2.5 \mu \mathrm{m})$. The modelled results indicate that small aerosol load, with an extinction of $0.08 \mathrm{~km}^{-1}$, is confined in a layer $100 \mathrm{~m}$ thick over the surface on 14 and 25 March. This confirms that there is a measured concentration of particles present in the lower surface air at the OOTI site. These 

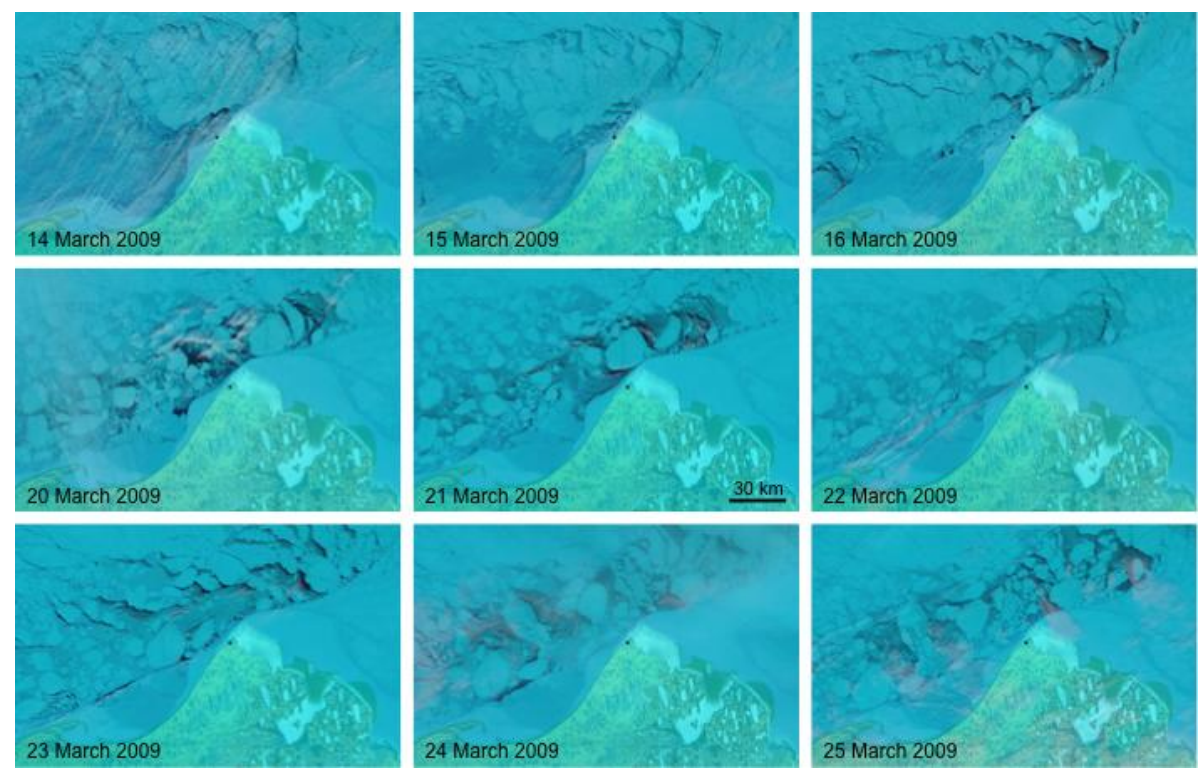

Fig. 3. MODIS satellite images of the sea ice conditions for 14-25 March 2009: 14-16 March, 20-22 March and 23-15 March are when samples were collected over the sea ice at sites 1, 2 and 3, respectively. 14-16 March represents Event 1; 20, 21 and 24 March represent Event 2, and 25 March represents Event 3. The black dot indicates the sampling location. The colours represent as follows: very light blue (lake ice or ice lagoon); light blue (first-year or older sea ice); darker blue (thinner and younger sea ice) and black (open water or thin new/nilas ice).

results further suggest that, on the afternoon of 25 March, an increased aerosol load (extinction coefficient of $0.3 \mathrm{~km}^{-1}$ ) is homogeneously distributed within $350 \mathrm{~m}$ from the surface and emerged following a shift of the wind direction from $225^{\circ}$ to $25^{\circ}$ and an increase in wind speed. This shift correlates to a shift in the PHg and RGM distribution.

Natural sea salt, aged sea salt and other mixed particles are ubiquitous over the sea ice. In Ny-Ålesund, these particles fall into the $>0.5 \mu \mathrm{m}$ size fraction range (Weinbruch et al., 2012). Other particle types commonly measured around the Arctic Ocean include sea salt sulphate, Arctic haze particles such as non-sea-salt sulphate and soot/black carbon. Sea salt sulphate aerodynamic diameters have been measured in the North Atlantic greater than $0.95 \mu \mathrm{m}$ but are lower in the springtime to a size less than $0.49 \mu \mathrm{m}$ (Seguin et al., 2011). Non-sea-salt sulphate diameter ranges between 0.49 and $0.95 \mu \mathrm{m}$ (Seguin et al., 2011). Another type of suspended particle reported around the Arctic Ocean is diamond dust (Douglas et al., 2008; Domine et al., 2011). These small needle-like crystals form in the air on clear, cold days and have a relatively large surface area on which reactions can occur. They are reported to have a length between 1 and $1000 \mu \mathrm{m}$ (Ohtake et al., 1982; Walden et al., 2003; Intrieri and Shupe, 2004). Douglas et al. (2008) reported high total $\mathrm{Hg}$ concentrations of $92-1370 \mathrm{ng} \mathrm{L}^{-1}$ in these crystals and concluded that they are likely a source of elevated $\mathrm{Hg}$ measured on the surface. The size of diamond dust is, for the most part, greater than the inlet cut-off of the mercury instrument $(2.5 \mu \mathrm{m})$. However, as the ice crystals hit the impactor on the instrument, there is potential for them to shatter and be measured by the instrument (Leaitch, personal communication to A. Stefffen, 2012). The contribution from diamond dust to the total particle load is likely minor but cannot be ruled out as a contributor to PHg levels because the $\mathrm{Hg}$ concentration in them is so high. PHg reported here is likely capturing the particles described above at this location over the sea ice. Interestingly, in 2005, RGM measurements collected in Barrow inland from the sea ice (approximately $0.5 \mathrm{~km}$ ) around the same time of year exceeded $800 \mathrm{pg} \mathrm{m}^{-3}$ at times, which may suggest significantly higher RGM concentrations inland than over the sea ice (Douglas et al., 2008). Unfortunately, $\mathrm{PHg}$ concentrations were not measured during that study to compare with the current one.

It is likely that low temperatures and the availability of sea salt and sulphate aerosols, as well as ice crystals around the sea ice, enable the RGM formed in the atmosphere to adsorb onto particles and result in the predominance of $\mathrm{PHg}$ measured over the sea ice. This finding is significant as the majority of mass balance calculations investigating the impact of AMDEs over the whole Arctic have relied on data collected inland or at coastal sites where sea salts may not be as predominant as over the ocean. Thus, current mass balance calculations may not accurately reflect the concentration of $\mathrm{PHg}$ over the sea ice. 
A)

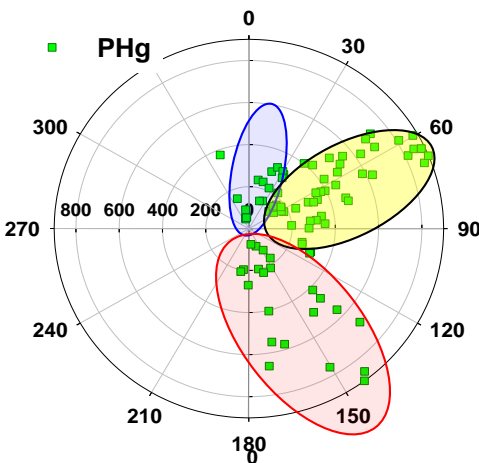

C)

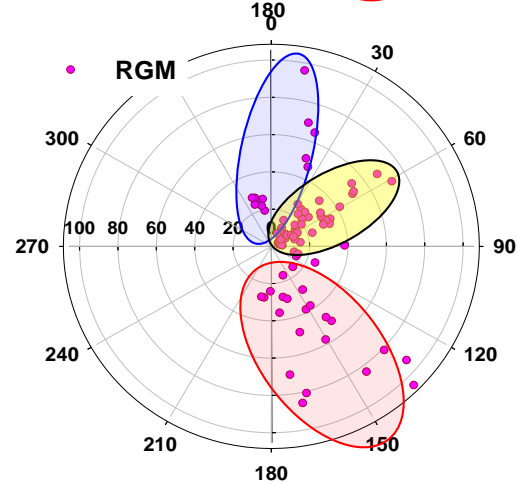

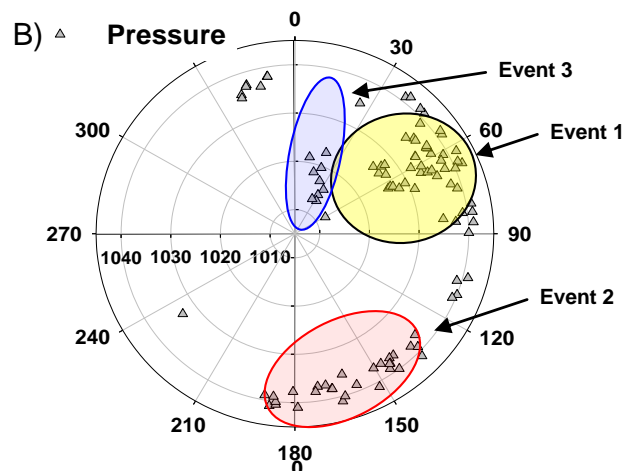

D)

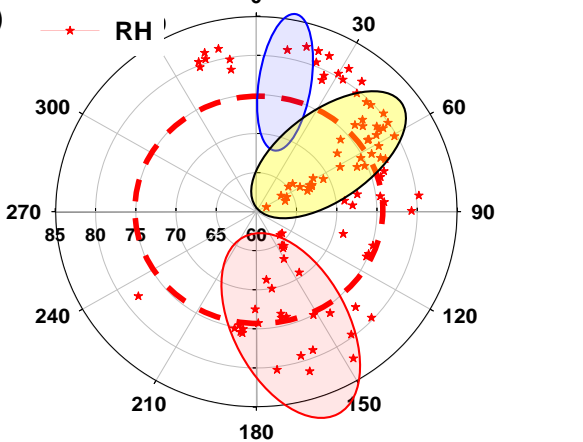

Fig. 4. Wind roses of (A) PHg concentration data $\left(\mathrm{pg} \mathrm{m}^{-3}\right)$, (B) air pressure (mB), (C) RGM concentration data $\left(\mathrm{pg} \mathrm{m}^{-3}\right)$ and (D) percent relative humidity (\%) for the data from 14 to 27 March 2009 from over the sea ice. Yellow, red and blue circles represent events 1, 2 and 3, respectively.

\subsection{Mercury, meteorology and sea ice}

In order to understand what could influence atmospheric mercury speciation concentration data over the sea ice, several atmospheric factors are investigated. Not surprisingly, a strong relationship between RGM and solar radiation is found which indicates that RGM is derived through photochemical reactions. PHg concentrations do not peak with solar radiation but lag behind by a few hours, suggesting that this fraction of $\mathrm{Hg}$ is not directly formed by photochemical processes. The highest peaks in PHg (Fig. 2: 15 and $21 \mathrm{March})$ are found when the air temperature is at the lowest $\left(<-30^{\circ} \mathrm{C}\right)$, the wind speeds are low (between 1 and $2 \mathrm{~m} \mathrm{~s}^{-1}$ ), relative humidity ( $\mathrm{RH}$ ) is below the average and the solar radiation is in a low period. The meteorological conditions reported on these days are ones in which ice crystals (diamond dust) can form in the air and provide a surface onto which newly formed RGM can adhere. Low temperatures also favour the partitioning of semi-volatile RGM compounds to the particle phase (Amos et al., 2012). Direct observations of diamond dust events were made on 21 and 22 March 2009 (Domine et al., 2011), raising the interesting hypothesis that RGM partitioning onto these crystals is the cause for the peak in PHg. The RGM and PHg data on these days differ from the other times in that they both peak during low solar radiation. The authors suggest that at the beginning of this time period RGM increases but that, as dia- mond dust crystals begin to form, some of this RGM adsorbs to these crystals and is detected as PHg. Such a shift would explain the atypical near-concurrent PHg and RGM peaks at this time.

Figure 4 shows the concentration of RGM and PHg, pressure and relative humidity in relation to wind direction. While these measurements were all made at locations surrounded by sea ice, the air coming from $330^{\circ}$ to $75^{\circ}$ is considered "from over the ocean only", while from $130^{\circ}$ to $210^{\circ}$ the air has originated from the "tundra" before travelling for a short distance over sea ice (see also Fig. 1a). The air pressure data (Fig. 4b) are first plotted with wind direction, and the clear groupings of air pressure and wind direction were used to define three air system events (the circles in the figure). The $\mathrm{Hg}$ data are grouped as "events 1, 2 and 3" according to these air systems. Table 2 summarizes the data shown in Fig. 4 and shows the mean and range of values for wind direction, air pressure, \% RH, PHg and RGM concentration. Table 2 also includes $r^{2}$ values from linear regressions between $\mathrm{PHg}$ and $\mathrm{RGM}$ with ozone and $\mathrm{BrO}$ for the entire period and for each of the three events. The dates of these events are as follows: Event 1: 14-19 March; Event 2: 20, 21, 24 and 25 March; and Event 3: 25-26 March. The results in Fig. 4 show that when the air is from around $60^{\circ}$ (Event 1 yellow circle - sea ice) PHg is above the total mean concentration and RGM is below. When the air is coming from $150^{\circ}$ (Event 2 red circle - tundra), RGM is above its 
Table 2. Summary information for data collected over the sea ice for the total study period and events 1, 2 and 3.

\begin{tabular}{|c|c|c|c|c|c|}
\hline & Units & Total & $\begin{array}{l}\text { Event } 1 \\
\text { (yellow) }\end{array}$ & $\begin{array}{l}\text { Event } 2 \\
\quad \text { (red) }\end{array}$ & $\begin{array}{c}\text { Event } 3 \\
\text { (blue) }\end{array}$ \\
\hline Dates & & 14-26 March & 14-19 March & 20, 21, 24 March & 25-26 March \\
\hline $\begin{array}{l}\text { Wind direction } \\
\text { Centre (range) }\end{array}$ & Degree & $\begin{array}{l}210-330 \\
(30-90)\end{array}$ & $\begin{array}{c}60 \\
(120-180)\end{array}$ & $\begin{array}{c}150 \\
(0-30)\end{array}$ & 15 \\
\hline $\begin{array}{l}\text { Air pressure } \\
\text { Mean (range) }\end{array}$ & mbar & $\begin{array}{c}1035 \\
(1012-1042)\end{array}$ & $\begin{array}{c}1035 \\
(1026-1041)\end{array}$ & $\begin{array}{c}1038 \\
(1035-1042)\end{array}$ & $\begin{array}{c}1019 \\
(1012-1035)\end{array}$ \\
\hline $\begin{array}{l}\text { PHg concentration } \\
\text { Mean (range) }\end{array}$ & $\mathrm{pg} \mathrm{m}^{-3}$ & $\begin{array}{c}393.5 \\
(47.1-900.1)\end{array}$ & $\begin{array}{c}449.8 \\
(123.1-898.9)\end{array}$ & $\begin{array}{c}367.4 \\
(47.1-900.1)\end{array}$ & $\begin{array}{c}255.5 \\
(140.2-319.6)\end{array}$ \\
\hline $\begin{array}{l}\text { RGM concentration } \\
\text { Mean (range) }\end{array}$ & $\mathrm{pg} \mathrm{m}^{-3}$ & $\begin{array}{c}30.1 \\
(3.5-105.4)\end{array}$ & $\begin{array}{c}18.3 \\
(3.5-71.8)\end{array}$ & $\begin{array}{c}39.4 \\
(12.8-105.4)\end{array}$ & $\begin{array}{c}42.9 \\
(7.4-95.7)\end{array}$ \\
\hline $\begin{array}{l}\% \text { relative humidity } \\
\text { mean (range) }\end{array}$ & percent & $\begin{array}{c}74.8 \\
(61.3-82.3)\end{array}$ & $\begin{array}{c}71.5 \\
(61.7-78.7)\end{array}$ & $\begin{array}{c}75.9 \\
(64.2-82.3)\end{array}$ & $\begin{array}{c}80.7 \\
(78.2-81.9)\end{array}$ \\
\hline $\begin{array}{l}R^{2} \text { with Ozone } \\
\mathrm{PHg} / \mathrm{RGM}\end{array}$ & $\mathrm{n} / \mathrm{a}$ & $0.61 / 0.10$ & $0.82 / 0.01$ & $0.63 / 0.19$ & $0.58 / 0.29$ \\
\hline $\begin{array}{l}R^{2} \text { with } \mathrm{BrO} \\
\text { GEM/PHg/ RGM }\end{array}$ & $\mathrm{n} / \mathrm{a}$ & $0.48 / 0.1 / 0.36$ & $0.58 / 0.08 / 0.74$ & $0.04 / 0.14 / 0.01$ & $0.03 / 0.03 / 0.37$ \\
\hline Number of data points & $\mathrm{n} / \mathrm{a}$ & $96-101$ & $37-44$ & $42-50$ & $10-12$ \\
\hline
\end{tabular}

total mean and PHg is just below its total mean (but includes the high $\mathrm{PHg}$ peak discussed above). When the air is coming from $15^{\circ}$ (Event 3 blue circle - sea ice), RGM is above its total mean and PHg is well below. Events 1 and 3 show discernable characteristics, while Event 2 does not (air originating from over the tundra).

The average RH during events 1, 2 and 3 are below $75 \%$, around $75 \%$ and above $75 \%$, respectively, as seen in Table 2 . These results show that there may be a relationship between the concentration of either PHg or RGM and RH. The deliquescence point of $\mathrm{NaCl}$ is at $75 \% \mathrm{RH}$ (Chen and Lee, 2001), which could indicate that these particles would have absorbed water, grown to where they could be more readily removed from the air at this point, are too large to be sampled $(>2.5 \mu \mathrm{m})$ or have reached a point where RGM is less likely to partition onto the sea salt and remain in the air. Air temperature can also play a role in the frequency of AMDEs (Cole and Steffen, 2010). In this study, air temperatures are investigated with $\mathrm{PHg}$ and $\mathrm{RGM}$ over the sea ice. $\mathrm{PHg}$ is positively correlated (linearly) with air temperature $\left(r^{2}=0.53\right)$, but RGM shows no linear relationship with temperature.

The distances between the sample locations and the nearest refrozen ice/open water or nilas ice are estimated using MODIS satellite images. These estimates are summarized in Table 3 and are separated into events 1, 2 and 3 to assess whether there are links between the proximity of certain sea ice and mercury concentrations. During Event 1, a strong depletion of GEM and elevation in $\mathrm{PHg}$ are reported when the sampling site was located close to refrozen sea ice
$(1.2-1.8 \mathrm{~km})$. At this time, the air measured is directly from the direction of this refrozen lead and is concurrent with the low GEM and high PHg concentrations. At the beginning of Event 2, the refrozen sea ice is further away from the sampling site $(4-5 \mathrm{~km})$ but an open lead is within $8 \mathrm{~km}$. The proximity of the open lead may explain the increase in the \% RH if the air mass with moisture from the lead came near the study site; however the wind direction during this event is predominately from the south, and thus the chemistry is not likely impacted from this lead. On March 25, during Event 3, open leads are closer at $12.5 \mathrm{~km}$ to the measurement and GEM is again depleted. These results suggest that both open leads and recently frozen sea ice are associated with GEM loss and with differences between RGM and PHg concentration levels.

\subsection{Mercury, ozone and halogens over the sea ice}

The relationship between GEM and ozone $\left(\mathrm{O}_{3}\right)$ has been well documented during AMDEs in the Arctic springtime (Schroeder et al., 1998; Ebinghaus et al., 2002; Berg et al., 2003a; Poissant and Pilote, 2003; Skov et al., 2004). The correlation suggests that common chemistry is responsible for the depletion of both. Linear regressions are performed on GEM, $\mathrm{PHg}$ and $\mathrm{RGM}$ with $\mathrm{O}_{3}$ for the whole study period and for each event (Tables 1 and 2). GEM and $\mathrm{O}_{3}$ show a strong linear relationship over the sea ice $\left(r^{2}=0.76\right)$. While there is a reasonable linear relationship between $\mathrm{PHg}$ and $\mathrm{O}_{3}$ over the study period $\left(r^{2}=0.61\right)$, the strongest relationship was reported during Event $1\left(r^{2}=0.82\right)$. There is little re- 


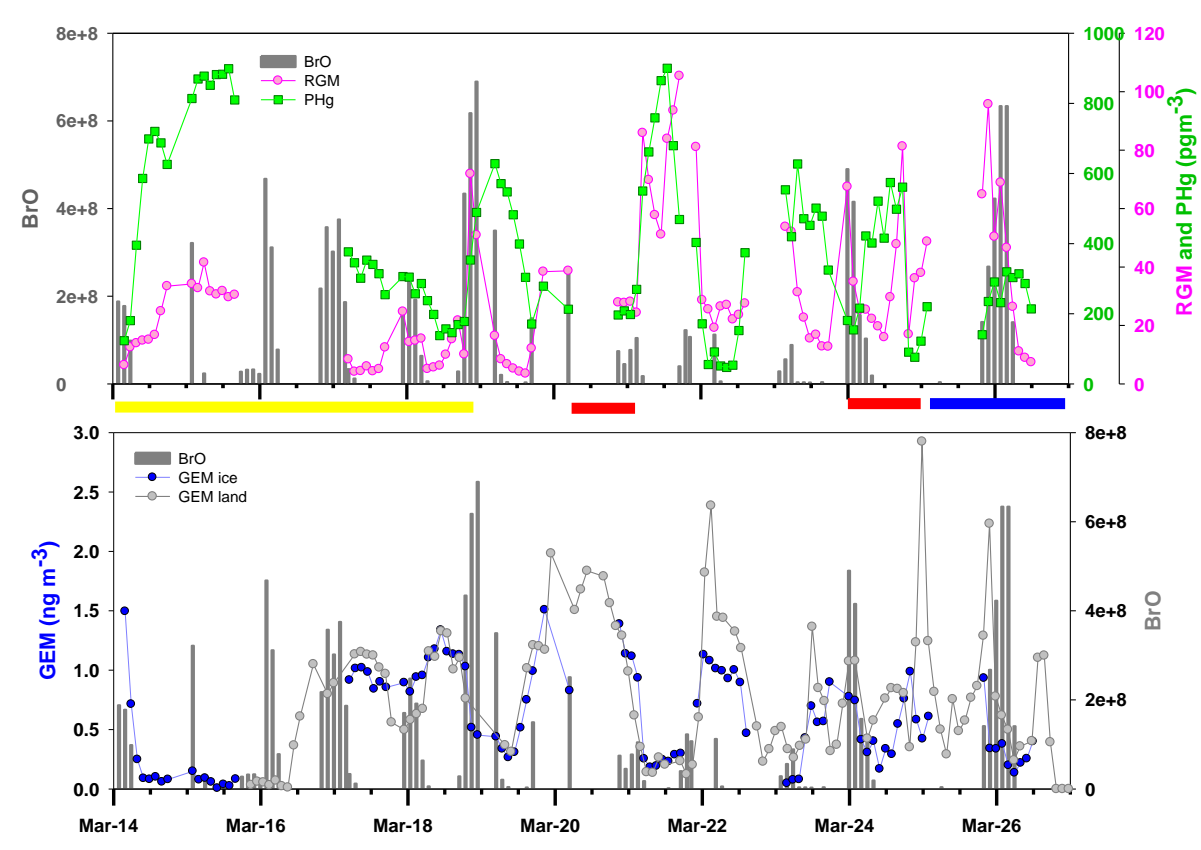

Fig. 5. $\mathrm{BrO}$ and $\mathrm{PHg} / \mathrm{RGM}$ measurements over the sea ice and $\mathrm{BrO}$ and GEM measurements over both tundra and sea ice. Events 1,2 and 3 are marked as yellow, red and blue, respectively.

Table 3. Estimated distances from the sampling locations on the sea ice to the nearest refrozen sea ice and nearest open water or nilas according to date and event.

\begin{tabular}{lccc}
\hline Date & $\begin{array}{c}\text { Distance to nearest } \\
\text { refrozen sea ice } \\
(\mathrm{km})\end{array}$ & $\begin{array}{c}\text { Distance to nearest } \\
\text { open water or nilas } \\
(\mathrm{km})\end{array}$ & $\begin{array}{c}\text { Corresponding } \\
\text { event }\end{array}$ \\
\hline 14 March & 1.4 & 11.0 & 1 \\
15 March & 1.2 & 7.0 & 1 \\
16 March & 1.8 & 9.0 & 1 \\
20 March & 4.4 & 5.4 & 2 \\
21 March & 5.0 & 8.5 & 2 \\
22 March & 5.8 & 45.0 & \\
23 March & 6.7 & 29.6 & 2 \\
24 March & 6.8 & 18.8 & 3 \\
25 March & 6.3 & 12.5 & \\
\hline
\end{tabular}

lationship between $\mathrm{O}_{3}$ and RGM in this data; however, the lifetime of RGM is short, and thus a strong relationship is not expected (Simpson et al., 2007).

Measurements of $\mathrm{BrO}$ are also collected during this study and Fig. 5 shows the time series of RGM, PHg, GEM and BrO. Table 2 shows the correlations of the mercury species with $\mathrm{BrO}$ (for the ice data). It can be seen in Fig. 5 that $\mathrm{BrO}$ is elevated at the beginning of a depletion event when GEM decreases and RGM/PHg increase and, as the event continues, $\mathrm{BrO}$ subsequently decreases. The results in Table 2 show that there is little to no linear relationship between $\mathrm{BrO}$ and $\mathrm{PHg}$ but a reasonable correlation between $\mathrm{BrO}$ and $\mathrm{RGM}$ for the periods when the air originates from over the ocean (Event 1 and especially Event 3). RGM and $\mathrm{BrO}$ are both products of bromine atom chemistry, which suggests that this chemistry is at play. The atmospheric conditions for Events 1 and 3 are as follows: Event 1 has high PHg, RH below $75 \%$, air temperature below $-25^{\circ} \mathrm{C}$, a positive correlation between $\mathrm{RGM}$ and $\mathrm{BrO}$ and a negative correlation between $\mathrm{PHg}$ and $\mathrm{O}_{3}$. These conditions can promote $\mathrm{Br}$ formation that, in turn, leads to RGM production where, under cold temperatures, the particles in the air provide the surface onto which RGM can adsorb and lead to elevated PHg concentrations. Event 3 has low $\mathrm{PHg}, \mathrm{RH}$ above $75 \%$, air temperature above $-25^{\circ} \mathrm{C}$, and again a positive correlation between RGM and $\mathrm{BrO}$, and a negative correlation between $\mathrm{PHg}$ and $\mathrm{O}_{3}$. The absence of a BrO-RGM correlation in Event 2 may result from the high-diamond-dust and high-PHg event that occurred on 21-22 March. As well, the lifetimes of $\mathrm{BrO}$ and RGM are quite different, which makes a direct analysis of these chemicals challenging ( $\mathrm{BrO}$ has a reported lifetime of 2 minutes and RGM, depending on the species, approximately 3.7 days (Corbitt et al., 2011)). However, given their high correlation during events 1 and 3, the lifetime of RGM may be closer to that of $\mathrm{BrO}$ under some Arctic conditions. If true, this suggests that the assumption that RGM is predominant over $\mathrm{PHg}$ in air masses experiencing active AMDE chemistry may not be accurate in very cold or particle-rich air masses.

\subsection{Atmospheric mercury differences between sea ice and inland tundra}

The difference between GEM concentrations over the sea ice and inland over the snow-covered tundra is also investigated. A summary of the GEM concentrations for the two 


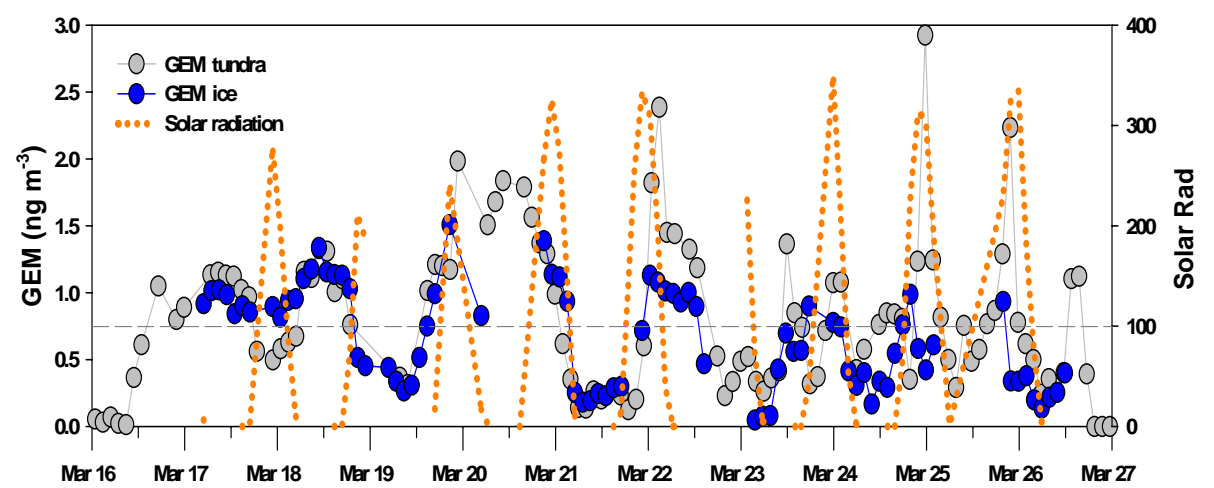

Fig. 6. GEM measurements over tundra inland (grey circles), over the sea ice (blue circles), solar radiation (orange) and the defined threshold for mercury depletions $\left(0.77 \mathrm{ng} \mathrm{m}^{-3}\right)$ (dashed grey line).

locations is shown in Table 1 . The mean GEM concentration, with $95 \%$ confidence interval, over the tundra is significantly higher $\left(0.79 \pm 0.11 \mathrm{ng} \mathrm{m}^{-3}\right)$ than that recorded over the sea ice $\left(0.59 \pm 0.08 \mathrm{ng} \mathrm{m}^{-3}\right)$. The minimum concentration at both locations is the same, but the maximum over the tundra is higher than over the ice (2.92 and $1.51 \mathrm{ng} \mathrm{m}^{-3}$, respectively). A linear correlation between $\mathrm{O}_{3}$ and GEM is made for both sites and the results are shown in Table 1 . These results show that there is a stronger linear relationship of $\mathrm{O}_{3}$ and GEM over the sea ice than inland, as reflected by $r^{2}$ values of 0.76 and 0.52 , respectively. This and the higher inland mean GEM concentration can be explained by inspecting the GEM concentrations from each site together. Figure 6 shows the time series from GEM measurements inland over the tundra (grey circles) and from over the sea ice (blue circles), the solar radiation (orange dots) and the defined depletion concentration threshold (dashed grey line). This plot shows that both sites experience depletion events around the same time and to the same level throughout most of the study. The striking difference between these two data sets is the strong peaks of GEM at the tundra site following the end of a depletion event which are not concurrently observed over the ocean. GEM (and $\mathrm{O}_{3}$ ) concentrations generally do return to background after depletion through mixing (generally from aloft). However, it has also been shown that some GEM is emitted from the snowpack following depletion events (Steffen et al., 2002; Poulain et al., 2004; Kirk et al., 2006), likely due to photoreduction processes of oxidized mercury (Lalonde et al., 2002; Poulain et al., 2004; Durnford and Dastoor, 2011). The strong peaks of GEM at the tundra site at the end of an AMDE indicates that the amount of GEM returning to the air is much higher (nearly double in concentration) than that over sea ice. These results suggest that emission of GEM from the tundra snowpack occurs with a different magnitude than the emission recorded over the sea ice. The instruments were run beside each other for several days: a correlation of 0.9 was found for GEM, and thus the differences are not a result of instrument bias. It is also observed that after a spike in GEM concentrations at both lo- cations the GEM is again oxidized and depleted from the air. This cycle continued throughout the study.

We hypothesize that the much smaller size of the GEM spikes over the sea ice is due to the presence of large quantities of $\mathrm{NaCl}$ in the snow over the ocean surface. It was suggested by Poulain et al. (2004) and Lehnherr and St. Louis (2009) that the photoreduction of oxidized $\mathrm{Hg}$ is suppressed by the presence of chloride. To investigate this further, snow samples from over the sea ice and around the land tundra site were collected and analysed for major ions and total $\mathrm{Hg}$. The samples were collected randomly (for the purpose of this investigation) over the study period and thus were averaged for overall concentrations rather than reported daily. The overall results show that the average concentration of mercury in the surface snow over land (16 samples) and sea ice (13 samples) are $66 \pm 30$ (range $25-136) \mathrm{ng} \mathrm{L}^{-1}$ and $75 \pm 47$ (range 34-212) $\mathrm{ng} \mathrm{L}^{-1}$, respectively. These results indicate that there is somewhat more $\mathrm{Hg}$ in snow over the ice than over the tundra; however, there is high variability in this data. While a Mann-Whitney $U$ test showed that these concentrations are not statistically different ( $95 \%$ confidence), they do follow the pattern of previously reported results where concentrations of mercury in the snow are lower further inland from the coast (Douglas et al., 2008). However, the major ion data show that the chloride are six times higher in the snow over the sea ice than the tundra while bromide concentrations are twice as high in snow over the sea ice than the tundra. Higher concentration of chloride in the snow over the sea ice supports the hypothesis that the lower emission of GEM over the sea ice (in comparison with the tundra) is caused by a suppression of the photoreduction of RGM/PHg by chloride. The important corollary is that the sea ice snow can retain substantially more mercury than surface snow inland. The conclusion that the sea ice snow retains more mercury than tundra snow is a significant finding that needs to be factored into the current models investigating the cycling of mercury in the Arctic Ocean region. 


\section{Conclusions}

In March 2009, measurements of GEM, RGM and PHg were collected near new sea ice and open leads and fractures in the Chukchi/Beaufort Sea near Barrow, Alaska, as part of the OASIS and OASIS-Canada International Polar Year programmes. These results represent the first published atmospheric mercury speciation measurements collected and reported on the sea ice. Concurrent observations of ozone, bromine oxide and a suite of meteorological parameters are also reported to explore their role of the atmosphere in the cycling of mercury over the sea ice. High levels of PHg associated with low air temperatures and RH below $75 \%$ over the sea ice. The average PHg concentration was substantially higher than RGM over the sea ice. Sea salts and ice crystals around the sea ice provide surfaces to which RGM, created through AMDEs, could adsorb. Three distinct events occurred during the study that reflected different air masses and allowed study of the conditions and mercury speciation. Higher PHg concentrations than RGM are observed when measuring close to a refrozen lead. It was shown that, when $\mathrm{O}_{3}$ and $\mathrm{BrO}$ chemistry was active, there were linear relationships between GEM, PHg and $\mathrm{O}_{3}$ and between RGM and $\mathrm{BrO}$, demonstrating the complexity of the atmospheric chemistry associated with AMDEs.

GEM was measured simultaneously at sites over the tundra and the nearby sea ice. A comparison of these results shows a significant difference in the magnitude of the emission of GEM once AMDEs ceased at the two locations. Higher chloride concentrations in the snow over the sea ice are the most likely explanation for the lower GEM emission over the sea ice due to the suppression of photoreduction processes of RGM/PHg to GEM in the presence of chloride. We conclude that the sea ice snow retains substantially more mercury than surface snow inland. This result needs to be factored into modelling efforts predicting the impacts of sea ice changes on the mercury cycle over the Arctic Ocean.

The sea ice on the Arctic Ocean is rapidly moving toward a greater fraction of thinner, more dynamic first-year ice with the following characteristics: more open leads, enhanced sea salt particle formation, more new ice formation, more frost flowers, and more brine wicking to the ice surface (Douglas et al., 2012a). As a consequence, the future Arctic Ocean sea ice and snowpack regime are expected to be increasingly halogen- and sea-salt-rich. This could have major implications for the deposition and ultimate fate of mercury in the Arctic for two reasons. Firstly, these properties of first-year ice are believed to support the activation of sea salt bromide (Nghiem et al., 2012), and therefore this scenario would likely result in increased atomic bromine concentrations and hence more widespread AMDEs in the Arctic atmosphere. Secondly, the more sea salt available on the surface of the Arctic Ocean (and potentially inland), the more deposited mercury may be retained. Thus, the present (and future) Arctic Ocean is likely a larger sink for atmospheri- cally deposited mercury than has been previously been realized from field and modelling activities. Any potential for snow enriched in sea salts to move from the sea ice to the land in coastal environments will have higher mercury retention and thus a stronger impact of AMDEs on the coastal ecosystems.

Acknowledgements. The authors would like to thank Environment Canada and the Canadian International Polar Year programme for funding this project. T. Douglas acknowledges instrumentation support from the US Army Cold Regions Research and Engineering Laboratory and financial support from the US National Science Foundation and the US National Aeronautics and Space Administration. Logistical support in Barrow was provided by the Barrow Arctic Science Consortium. The authors thank Patrick Lee for field technical support and Julie Narayan for data analysis support. The research carried out at the Jet Propulsion Laboratory, California Institute of Technology, was supported by the National Aeronautics and Space Administration (NASA) Cryospheric Sciences Program.

Edited by: A. Dastoor

\section{References}

Amos, H. M., Jacob, D. J., Holmes, C. D., Fisher, J. A., Wang, Q., Yantosca, R. M., Corbitt, E. S., Galarneau, E., Rutter, A. P., Gustin, M. S., Steffen, A., Schauer, J. J., Graydon, J. A., Louis, V. L. St., Talbot, R. W., Edgerton, E. S., Zhang, Y., and Sunderland, E. M.: Gas-particle partitioning of atmospheric $\mathrm{Hg}$ (II) and its effect on global mercury deposition, Atmos. Chem. Phys., 12, 591-603, doi:10.5194/acp-12-591-2012, 2012.

Aspmo, K., Temme, C., Berg, T., Ferrari, C., Gauchard, P.-A., Fain, P.-A., and Wibetoe, G.: Mercury in the Atmosphere, Snow and Melt Water Ponds in the North Atlantic Ocean during Arctic Summer, Environ. Sci. Technol., 40, 4083-4089, 2006.

Berg, T., Sekkesæter, S., Steinnes, E., Valdal, A. K., and Wibetoe, G.: Springtime depletion of mercury in the European Arctic as observed at Svalbard, Sci. Total Environ., 304, 43-51, 2003a.

Berg, T., Sommar, J., Wängberg, I., Gårdfeldt, K., Munthe, J., and Schroeder, W. H.: Arctic mercury depletion events at two elevations as observed at the Zeppelin Station and Dirigibile Italia, Ny-Ålesund, spring 2002, J. Phys. IV, 107, 151-154, 2003 b.

Bottenheim, J. and Chan, E.: A trajectory study into the origin of spring time Arctic boundary layer ozone depletion, J. Geophys. Res., 111, D19301, doi:10.1029/2006JD007055, 2006.

Bottenheim, J. W., Netcheva, S., Morin, S., and Nghiem, S. V.: Ozone in the boundary layer air over the Arctic Ocean: measurements during the TARA transpolar drift 2006-2008, Atmos. Chem. Phys., 9, 4545-4557, doi:10.5194/acp-9-4545-2009, 2009.

Chaulk, A., Stern, G. A., Arnstrong, D., Barber, D. G., and Wang, F.: Mercury distribution and transport across the ocean-sea-iceatmosphere interface on the arctic ocean, Environ. Sci. Technol., 45, 1866-1872, doi:10.1021/es103434c, 2011.

Chen, Y. Y. and Lee, W. M.: The effect of surfactants on deliquescence of sodium chloride, J. Environ. Sci. Heal. A, 36, 229-242, 2001. 
Cobbett, F. D., Steffen, A., Lawson, G., and Van Heyst, B. J.: GEM fluxes and atmospheric mercury concentrations (GEM, RGM and $\mathrm{HgP}$ ) in the Canadian Arctic at Alert, Nunavut, Canada (February-June 2005), Atmos. Environ., 41, 6527-6543, 2007.

Cole, A. S. and Steffen, A.: Trends in long-term gaseous mercury observations in the Arctic and effects of temperature and other atmospheric conditions, Atmos. Chem. Phys., 10, 4661-4672, doi:10.5194/acp-10-4661-2010, 2010.

Cole, A. S., Steffen, A., Pfaffhuber, K. A., Berg, T., Pilote, M., Poissant, L., Tordon, R., and Hung, H.: Ten-year trends of atmospheric mercury in the high Arctic compared to Canadian subArctic and mid-latitude sites, Atmos. Chem. Phys., 13, 15351545, doi:10.5194/acp-13-1535-2013, 2013.

Constant, P., Poissant, L., Villemur, R., and Lean, D.: Fate of mercury and methylmercury within the snow cover at Whapmagoostui-Kuujjuarapik (Québec, Canada), J. Geophys. Res.-Atmos., 112, D08309, doi:10.1029/2006JD007961, 2007.

Corbitt, E. S., Jacob, D. J., Holmes, C. D., Streets, D. G., and Sunderland, E. M.: Global source-receptor relationships for mercury deposition under present-day and 2050 emissions scenarios, Environ. Sci. Technol., 45, 10477-10484, 2011.

Dastoor, A., Davignon, D., Theys, N., van Roozendael, M., Steffen, A., and Ariya, P.: Modeling dynamic exchange of gaseous elemental mercury at polar sunrise, Environ. Sci. Technol., 42, 5183-5188, 2008.

Deutchmann, T.: Applicability of light-emitting diodes as light sources for active long path DOAS measurements, $\mathrm{PhD}$, Physics, Univerity of Heidelberg, Heidelberg, 2009.

Domine, F., Gallet, J.-C., Barret, M., Houdier, S., Voisin, D., Douglas, T. A., Blum, J., Beine, H. J., Anastasio, C., and Breon, F.M.: The specific surface area and chemical composition of diamond dust near Barrow, Alaska, J. Geophys. Res., 116, 18 pp., doi:10.1029/2011JD016162, 2011.

Dommergue, A., Ferrari, C. P., Gauchard, P.-A., Boutron, C. F., Poissant, L., Pilote, M., Jitaru, P., and Adams, F.: The fate of mercury species in a sub-arctic snow-pack during snowmelt, Geophys. Res. Lett., 30, 23-21, doi:10.1029/2003GL017308, 2003.

Dommergue, A., Bahlmann, E., Ferrara, R., and Boutron, C. F.: Laboratory simulation of $\mathrm{Hg}^{0}$ emissions from a snowpack, Anal. Bioanal. Chem., 388, 319-327, 2007.

Douglas, T., Sturm, M., Simpson, W., Blum, J., Alvarez-Aviles, L., Keeler, G., Perovich, D., Biswas, A., and Johnson, K.: The influence of snow and ice crystal formation and accumulation on mercury deposition to the Arctic, Environ. Sci. Technol., 42, 15421551,2008

Douglas, T. A., Domine, F., Barret, M., Anastasio, C., Beine, H. J., Bottenheim, J., Grannas, A., Houdier, S., Netcheva, S., Rowland, G., Staebler, R., and Steffen, A.: Frost flowers growing in the Arctic ocean-atmosphere-sea ice-snow interface: 1. Chemical composition, J. Geophys. Res.-Atmos., 117, D00R09, doi:10.1029/2011JD016460, 2012a.

Douglas, T. A., Loseto, L. L., MacDonald, R., Outridge, P. M., Dommergue, A., Poulain, A. J., Amyot, J. D., Barkay, T., Berg, T., Chetelat, J., Constant, P., Evans, M. S., Ferrari, C., Gantner, N., Johnson, M. S., Kirk, J. L., Kroer, N., Larose, C., Lean, D., Nielsen, T. G., Poissant, L., Rognerud, S., Skov, H., Sorensen, S., Wang, F., Wilson, S., and Zdanowicz, C. M.: The fate of mercury in Arctic terrestrial and aquatic ecosystems, a review, Environ. Chem., 9, 321-355, doi:10.1071/EN11140, 2012b.
Durnford, D. and Dastoor, A.: The behavior of mercury in the cryosphere: A review of what we know from observations, J. Geophys. Res.-Atmos., 116, D06305, doi:10.1029/2010JD014809, 2011.

Durnford, D., Dastoor, A., Ryzhkov, A., Poissant, L., Pilote, M., and Figueras-Nieto, D.: How relevant is the deposition of mercury onto snowpacks? - Part 2: A modeling study, Atmos. Chem. Phys., 12, 9251-9274, doi:10.5194/acp-12-9251-2012, 2012.

Ebinghaus, R., Kock, H. H., Temme, C., Einax, J. W., Lowe, A. G., Richter, A., Burrows, J. P., and Schroeder, W. H.: Antarctic springtime depletion of atmospheric mercury, Environ. Sci. Technol., 36, 1238-1244, 2002.

Ebinghaus, R., Jennings, S. G., Kock, H. H., Derwant, R. G., Manning, A. J., and Spain, T. G.: Decreasing trends in total gaseous mercury in baseline air at Mace Head, Ireland from 1996-2009, Atmos. Environ., 159, 1577-1583, 2011.

Ferrari, C. P., Dommergue, A., and Boutron, C. F.: Profiles of mercury in the snow pack at Station Nord, Greenland shortly after polar sunrise, Geophys. Res. Lett., 31, L03401, doi:10.1029/2003GL018961, 2004.

Ferrari, C. P., Gauchard, P. A., Dommergue, A., Magand, O., Nagorski, S., Boutron, C. F., Temme, C., Bahlmann, E., Ebinghaus, R., Steffen, A., Banic, C., Aspmo, K., Berg, T., Planchon, F., and Barbante, C.: Snow to air exchange of mercury in an Arctic seasonal snow pack in Ny-Alesund, Svalbard, Atmos. Environ., 39, 7633-7645, 2005.

Fisher, J. A., Jacob, D. J., Soerensen, A. L., Amos, H. M., Steffen, A., and Sunderland, E. M.: Riverine source of Arctic Ocean mercury inferred from atmospheric observations, Nat. Geosci., 5, 499-504, doi:10.1038/ngeo1478, 2012.

Frieß, U., Monks, P. S., Remedios, J. J., Rozanov, A., Sinreich, R., Wagner, T., and Platt, U.: MAX-DOAS O4 measurements: A new technique to derive information on atmospheric aerosols: 2. Modeling studies, J. Geophys. Res., 111, D14203, doi:10.1029/2005JD006618, 2004.

Frieß, U., Monks, P. S., Remedios, J. J., Rozanov, A., Sinreich, R., Wagner, T., and Platt, U.: MAX-DOAS O4 measurements: A new technique to derive information on atmospheric aerosols: 2. Modeling studies, J. Geophys. Res., 111, D14203, doi:10.1029/2005JD006618, 2006.

Frieß, U., Sihler, H., Sander, R., Poehler, D., Yilmaz, S., and Platt, U.: The vertical distribution of $\mathrm{BrO}$ and aerosols in the Arctic: Measurements by active and passive differential optical absorption spectroscopy, J. Geophys. Res., 116, D00R04, doi:10.1029/2011/JD015938, 2011.

Holmes, C. D., Jacob, D. J., Corbitt, E. S., Mao, J., Yang, X., Talbot, R., and Slemr, F.: Global atmospheric model for mercury including oxidation by bromine atoms, Atmos. Chem. Phys., 10, 12037-12057, doi:10.5194/acp-10-12037-2010, 2010.

Hönninger, G. and Platt, U.: Observations of $\mathrm{BrO}$ and its vertical distribution during surface ozone depletion at Alert, Atmos. Environ., 36, 2481-2489, 2002.

Intrieri, J. M. and Shupe, M. D.: Characteristics and radiative effects of diamond dust over the Western Arctic Ocean Region, J. Climatol., 17, 2953-2960, 2004.

Jacobi, H.-W., Kaleschke, L., Richter, A., Rozanov, A., and Burrows, J. P.: Observation of a fast ozone loss in the marginal ice zone of the Arctic Ocean, J. Geophys. Res., 111, D15309, doi:10.1029/2005JD006715, 2006. 
Kirk, J. L., St. Louis, V. L., and Sharp, M. J.: Rapid reduction and reemission of mercury deposited into snow packs during atmospheric mercury depletion events at Churchill, Manitoba, Canada, Environ. Sci. Technol., 40, 7590-7596, 2006.

Lalonde, J. D., Poulain, A. J., and Amyot, M.: The role of mercury redox reactions in snow on snow-to-air mercury transfer, Environ. Sci. Technol., 36, 174-178, 2002.

Landis, M., Stevens, R. K., Schaedlich, F., and Prestbo, E. M.: Development and characterization of an annular denuder methodology for the measurement of divalent inorganic reactive gaseous mercury in ambient air, Environ. Sci. Technol., 36, 3000-3009, 2002.

Latonas, J.: Measurements of Atmospheric Mercury, Dissolved Gaseous Mercury, and Evasional Fluxes in the Amundsen Gulf: The Role of the Sea-Ice Environment Masters, Department of Environment and Geography, University of Manitoba, Winnipeg, 165 pp., 2010.

Lehnherr, I. and St. Louis, V.: Importance of ultraviolet radiation in the photodemethylation of methylmercury in freshwater ecosystems, Environ. Sci. Technol., 43, 5692-5698, 2009.

Liao, J., Sihler, H., Huey, L. G., Neuman, J. A., Tanner, D. J., Friess, U., Playy, U., Flocke, F. M., Orlando, J. J., Shepson, P. B., Beine, H. J., Weinheimer, A. J., Sjostedt, S. J., Nowak, J. B., Knapp, D. J., Staebler, R. M., Zheng, W., Sander, R., Hall, S. R., and Ullmann, K.: A comparison of Arctic BrO measurements by chemical ionization mass spectrometry and long path differential optical absorption spectroscopy, J. Geophys. Res., 116, D00R02, doi:10.1029/2010JD014788, 2011.

Lindberg, S. E., Brooks, S., Lin, C.-J., Scott, K. J., Landis, M. S., Stevens, R. K., Goodsite, M., and Richter, A.: Dynamic oxidation of gaseous mercury in the Arctic troposphere at polar sunrise, Environ. Sci. Technol., 36, 1245-1256, 2002.

Lyman, S. N. and Gustin, M. S.: Speciation of atmospheric mercury at two sites in northern Nevada, USA, Atmos. Environ., 42, $927-$ 939, 2008.

Lynam, M. M., and Keeler, G. J.: Source-receptor relationships for atmospheric mercury in urban Detroit, Michigan, Atmos. Environ., 40, 3144-3155, 2006.

Nghiem, S., Rigor, I., Richter, A., Burrows, J. P., Shepson, P. B., Bottenheim, J., Barber, D. G., Steffen, A., Latonas, J., Wang, F., Stern, G., Clemente-Colón, P., Martin, S., Hall, D. K., Kaleschke, L., Tackett, P., Neumann, G., and Asplin, M. J.: Field and satellite observations of the formation and distribution of Arctic atmospheric bromine above a rejuvenated sea ice cover, J. Geophys. Res.-Atmos., 117, D00S05, doi:10.1029/2011JD016268, 2012.

Ohtake, T., Jayaweera, K., and Sakurai, K.-I.: Observation of ice crystal formation in lower arctic atmosphere, J. Atmos. Sci., 39, 2898-2904, 1982.

Platt, U. and Stutz, J.: Differential Optical Absorption Spectroscopy: Principles and Applications, Springer, Heidelberg, Germany, 2008.

Poissant, L. and Pilote, M.: Time series analysis of atmospheric mercury in Kuujjuarapik/Whapmagoostui (Quebec), J. Phys. IV, 107, 1079-1082, 2003.

Poissant, L., Pilote, M., Beauvais, C., Constant, P., and Zhang, H. H.: A year of continuous measurements of three atmospheric mercury species (GEM, RGM and Hgp) in southern Quebec, Canada, Atmos. Environ., 39, 1275-1287, 2005.
Poulain, A. J., Lalonde, J. D., Amyot, J. D., Shead, J. A., Raofie, F., and Ariya, P. A.: Redox transformations of mercury in an Arctic snowpack at springtime, Atmos. Environ., 38, 6763-6774, 2004.

Rutter, A. P. and Schauer, J. J.: The impact of aerosol composition on the particle to gas partitioning of reactive mercury, Environ. Sci. Technol., 41, 3934-3939, 2007.

Schroeder, W. H., Anlauf, K. G., Barrie, L. A., Lu, J. Y., Steffen, A., Schneeberger, D. R., and Berg, T.: Arctic springtime depletion of mercury, Nature, 394, 331-332, 1998.

Seabrook, J. A., Whiteway, J., Staebler, R. M., Bottenheim, J. W., Komguem, L., Gray, L. H., Barber, D., and Asplin, M.: Lidar measurements of Arctic boundary layer ozone depletion events over the frozen ocean, J. Geophys. Res.-Atmos., 116, D00S02, doi:10.1029/2011JD015938, 2011.

Seguin, A. M., Norman, A.-L., Eaton, S., and Wadleigh, M.: Seaonality in size segregated biogenic, anthorpogenic and sea salt sulfate aerosols over the North Atlantic, Atmos. Environ., 45, 69476954, 2011.

Sherman, L. S., Blum, J. D., Johnson, K. P., Keeler, G. J., Barres, J. A., and Douglas, T. A.: Mass-independent fractionation of mercury isotopes in Arctic snow driven by sunlight, Nat. Geosci., 3, 173-177, doi:10.1038/ngeo758, 2010.

Simpson, W. R., von Glasow, R., Riedel, K., Anderson, P., Ariya, P., Bottenheim, J., Burrows, J., Carpenter, L. J., Frieß, U., Goodsite, M. E., Heard, D., Hutterli, M., Jacobi, H.-W., Kaleschke, L., Neff, B., Plane, J., Platt, U., Richter, A., Roscoe, H., Sander, R., Shepson, P., Sodeau, J., Steffen, A., Wagner, T., and Wolff, E.: Halogens and their role in polar boundary-layer ozone depletion, Atmos. Chem. Phys., 7, 4375-4418, doi:10.5194/acp-74375-2007, 2007.

Skov, H., Christensen, J. H., Heidam, N. Z., Jensen, B., Wahlin, P., and Geernaert, G.: Fate of elemental mercury in the Artcic during atmospheric depletion episodes and the load of atmospheric mercury to the Arctic, Environ. Sci. Technol., 38, 2373-2382, 2004.

Slemr, F., Brunke, E., Ebinghaus, R., Temme, C., Munthe, J., Wängberg, I., Schroeder, W. H., Steffen, A., and Berg, T.: Worldwide trend of atmospheric mercury since 1977, Geophys. Res. Lett., 30, 23-21, 2003.

Slemr, F., Brunke, E.-G., Ebinghaus, R., and Kuss, J.: Worldwide trend of atmospheric mercury since 1995, Atmos. Chem. Phys., 11, 4779-4787, doi:10.5194/acp-11-4779-2011, 2011.

Steffen, A., Schroeder, W. H., Bottenheim, J., Narayan, J., and Fuentes, J. D.: Atmospheric mercury concentrations: measurements and profiles near snow and ice surfaces in the Canadian Arctic during Alert 2000, Atmos. Environ., 36, 2653-2661, 2002.

Steffen, A., Schroeder, W. H., Macdonald, R., Poissant, L., and Konoplev, A.: Mercury in the Arctic atmosphere: an analysis of eight years of measurements of GEM at Alert (Canada) and a comparison with observations at Amderma (Russia) and Kuujjuarapik (Canada), Sci. Total Environ., 342, 185-198, 2005.

Steffen, A., Douglas, T., Amyot, M., Ariya, P., Aspmo, K., Berg, T., Bottenheim, J., Brooks, S., Cobbett, F., Dastoor, A., Dommergue, A., Ebinghaus, R., Ferrari, C., Gardfeldt, K., Goodsite, M. E., Lean, D., Poulain, A. J., Scherz, C., Skov, H., Sommar, J., and Temme, C.: A synthesis of atmospheric mercury depletion event chemistry in the atmosphere and snow, Atmos. Chem. Phys., 8, 1445-1482, doi:10.5194/acp-8-1445-2008, 2008. 
Steffen, A., Cole, A., Dastoor, A., Antoniadis, M., Ariya, P., and Morrison, H.: Atmospheric Mercury, in: Canadian Arctic Contaminants Assessment Report III: Mercury in Canada's North, edited by: Braune, B. and Chetelat, J., Northern Contaminants Program (NCP), Aboriginal Affairs and Northern Development Canada, Ottawa, 276 pp., 2012a.

Steffen, A., Scherz, T., Olson, M. L., Gay, D. A., and Blanchard, P.: A comparison of data quality control protocols for atmospheric mercury speciation measurements, J. Environ. Monitor., 14, 752765, doi:10.1039/c2em10735j, 2012b.

Stern, G., Macdonald, R. W., Outridge, P. M., Wilson, S., Chetelat, J., Cole, A., Hintlemann, H., Loseto, L. L., Steffen, A., Wang, F., and Zdanowicz, C.: How does climate change influence arctic mercury?, Sci. Total Environ., 414, 22-42, 2012.

Wagner, T., Dix, B., von Friedeburg, C., Frieß, U., Sanghavi, S., Sinreich, R., and Platt, U.: MAX-DOAS O4 measurements: A new technique to derive information on atmospheric aerosolsPrinciples and information content, J. Geophys. Res., 109, D22205, doi:10.1029/2004JD004904, 2004.
Walden, V. P., Warren, S. G., and Tuttle, E.: Atmospheric ice crystals over the anrarctic plateau in winter, J. Appl. Meteorol., 42, 1391-1405, 2003.

Weinbruch, S., Wiesemann, D., Ebert, M., Schütze, K., Kallenborn, R., and Ström, J.: Chemical composition and sources of aerosol particles at Zeppelin Mountain (Ny Ålesund, Svalbard): An electron microscopy study, Atmos. Environ., 49, 142-150, 2012.

Zhang, L., Wright, L. P., and Blanchard, P.: A review of current knowledge concerning dry deposition of atmospheric mercury, Atmos. Environ., 43, 5853-5864, 2009. 